\title{
Spatial and Temporal Variations of Dissolved Oxygen in Cha- Am Municipality Wastewater Treatment Ponds Using GIS Kriging Interpolation
}

\author{
Shwesin Koko, ${ }^{1}$ Kim N. Irvine, ${ }^{2}$ Ranjna Jindal ${ }^{1}$ and Romanee Thongdara ${ }^{1}$ \\ ${ }^{1}$ Mahidol University, Thailand; ${ }^{2}$ Nanyang Technology University, Singapore.
}

\begin{abstract}
This study investigated the spatial and temporal variations in dissolved oxygen (DO) in the Cha-Am wastewater treatment ponds to assess treatment dynamics and to identify possible areas where the treatment train could be improved. Cha-Am is a small resort town with extensive beaches, located on the west coast of the Gulf of Thailand. The wastewater treatment system for Cha-Am consists of four ponds in sequence: aeration pond, sedimentation pond, extended aeration pond, and evaporation pond. Two YSI 6920 datasondes were installed near the inlet of the aeration pond and in the sedimentation pond, to measure dissolved oxygen (DO), pH, conductivity, temperature, and turbidity at $30 \mathrm{~min}$ time intervals over a 3 month period. DO averaged $3.09 \mathrm{mg} / \mathrm{L}$ and 3.33 $\mathrm{mg} / \mathrm{L}$, respectively in the aeration pond and in the sedimentation pond. DO generally varied over a diel cycle with higher values observed in midafternoon and lower values observed after midnight. DO often increased after a rainfall event. Ordinary Kriging (OK) interpolation in ArcGIS10.1 was used to map the spatial distribution of DO at different depths based on YSI spot measurements. OK indicated the highest DO concentrations were near the surface ( $0.5 \mathrm{~m}$ to $1.0 \mathrm{~m}$ ); averaging $18.53 \mathrm{mg} / \mathrm{L}, 20.5 \mathrm{mg} / \mathrm{L}, 17.31$ $\mathrm{mg} / \mathrm{L}$ and $9.7 \mathrm{mg} / \mathrm{L}$ in the four ponds, but sometimes the concentrations were $<2 \mathrm{mg} / \mathrm{L}$ near the bottom of the ponds. Two of the ponds are used as a wild catch fishery and low DO seems to negatively impact the fish. The spatial trend of DO shows that normally DO is lower at the inlet of the aeration pond than at its outlet even though mechanical aerators are operated through part of the day. Improved aeration and sunlight penetration through enhanced particle settling may be of benefit.
\end{abstract}

\section{Introduction}

Cha-Am is a small seaside resort town that is situated on the west coast of the Gulf of Thailand. It is located $175 \mathrm{~km}$ southwest of Bangkok and approximately $25 \mathrm{~km}$ north of Hua Hin. Because of increasing tourist visits to its extensive beaches and a growing permanent population, water consumption and corresponding wastewater generation have increased. A municipal wastewater treatment pond system has been in operation in Cha-Am since 2001. A sufficient oxygen supply in a wastewater pond system is the key to rapid and effective wastewater treatment (Bartsch and Randall 1971). Dissolved oxygen (DO) depends on the biochemical oxygen demand (BOD) (deoxygenation), nitrification, aeration, sedimentation, photosynthesis and algae respiration (Sakalauskiene 2001; see Figure 1 below ). Sources of DO in a waterbody are primarily the atmosphere and photosynthetic activity, with the latter being more important for lentic-type systems and the former more important for lotic systems (Andrews and McEwan 1987; Radwan et al. 2003; Correa-Gonzalez et al. 2014).

Microorganisms (e.g. aerobic bacteria) use oxygen in the oxidation of organic matter, as part of metabolism and nitrification processes, which directly affect oxygen concentration (USEPA 2012). When household, industrial, septic system and farm wastes are discharged into water, organic matter and nutrients are present in them. In an aeration lagoon system, these wastes are oxidized by bacteria and other biological species such as algae which can cause oxygen depletion (Misra et al. 2006). As originally outlined by Odum (1956), the rate of change of DO in an aquatic system is primarily a function of gross primary production, the rate of respiration, and the rate of oxygen uptake by diffusion. This can be expressed as (after McBride and Chapra 2005):

$$
\frac{d D}{d t}+k_{a} D=R-P(t)
$$

where:

$$
\begin{aligned}
D=C \text { sat } & -C \\
D & =\text { dissolved oxygen deficit }(\mathrm{mg} / \mathrm{L}), \\
\text { Csat } & =\text { saturated value }(\mathrm{mg} / \mathrm{L}), \\
C & =\text { DO concentration }(\mathrm{mg} / \mathrm{L}), \\
t & =\text { time }(\mathrm{d}),
\end{aligned}
$$

Koko,Shwesin, Kim N. Irvine, Ranjna Jindal and Romanee Thongdara. 2017. patial and Temporal Variations of Dissolved Oxygen in Cha-Am Municipality Wastewater Treatment Ponds Using GIS Kriging Interpolation. Journal of Water Management Modeling 25:C427.

https://doi.org/10.14796/JWMM.C427 @ CHI 2017. www.chijournal.org ISSN 2292-6062. 


$$
\begin{aligned}
k_{a}= & \text { first-order re-aeration coefficient }(/ \mathrm{d}), \\
R= & \text { respiration rate }\left(\mathrm{O}_{2} \mathrm{mg} / \mathrm{L} / \mathrm{d}\right), \text { and } \\
P(t)= & \text { time-varying plant primary production } \\
& \text { (photosynthesis) rate }\left(\mathrm{O}_{2} \mathrm{mg} / \mathrm{L} / \mathrm{d}\right) .
\end{aligned}
$$

Ammonia is primarily removed in lagoon systems by microbiological nitrification to nitrate. Lagoons often support nitrification and have low effluent ammonia concentrations (Richard 2003). This process also requires oxygen (Figure 1). At higher temperatures with high aeration rates, DO levels in water bodies will exceed $100 \%$, a condition known as supersaturation (Ling et al. 2010).

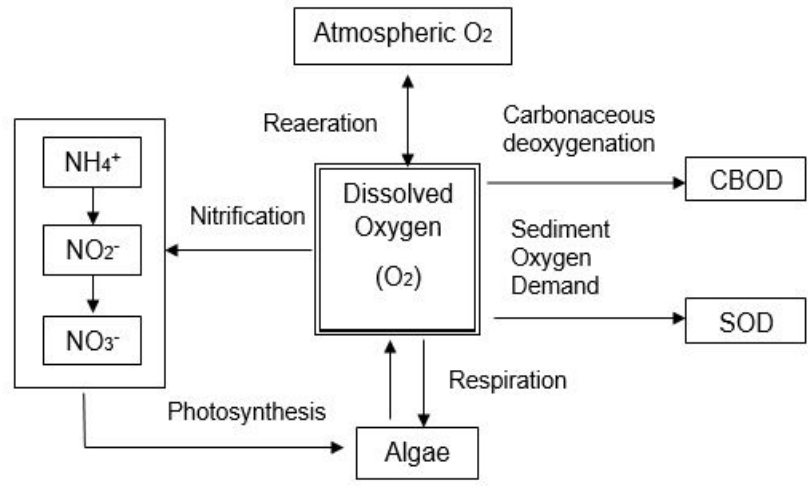

Figure 1 Dissolved oxygen balance (source: Sakalauskiene 2001).

The ambient water quality standards for DO in Thailand were established in 1994 and are based on a best use concept, as shown in Table 1 (Simachaya, 2002). In using aeration lagoon systems to treat wastewater, it is desirable that the discharge reach at least Class 3 levels, which means BOD and COD treatment also

\begin{tabular}{|c|c|c|}
\hline Classification & Condition & DO values \\
\hline Class 1 & Extra clean for conservation purposes. & - \\
\hline Class 2 & $\begin{array}{l}\text { Very clean used for: } \\
\text { consumption which requires ordinary water treatment } \\
\text { processes; } \\
\text { aquatic organism conservation; } \\
\text { fisheries; and } \\
\text { recreation. }\end{array}$ & $\mathrm{D} 0>6 \mathrm{mg} / \mathrm{L}$ \\
\hline Class 3 & $\begin{array}{l}\text { Medium clean used for: } \\
\text { consumption but passing through an ordinary } \\
\text { treatment process; and } \\
\text { agriculture. }\end{array}$ & $\mathrm{DO}>4 \mathrm{mg} / \mathrm{L}$ \\
\hline Class 4 & $\begin{array}{l}\text { Fairly clean used for: } \\
\text { consumption, but requires special treatment } \\
\text { processing; and } \\
\text { industry. }\end{array}$ & $\mathrm{D} 0>2 \mathrm{mg} / \mathrm{L}$ \\
\hline Class 5 & $\begin{array}{l}\text { Waters are not classified in classes } 1-4 \text { and are used for } \\
\text { navigation. }\end{array}$ & 一 \\
\hline
\end{tabular}
are important considerations.

Table 1 Thailand water quality standards for DO concentration.

Geographic information system (GIS) kriging is a spatial interpolation method to estimate a variable at an unmeasured location using observed values at nearby locations. Numerous studies have applied GIS kriging interpolation methods in the assessment of water and sediment quality to support management and remediation decision-making (Irvine et al. 2009; Murphy et al. 2010; Lui et al. 2011; Chen et al. 2012b; Forsythe et al. 2013). The primary objective of this study was to investigate the spatial variation of dissolved oxygen within the Cha-Am aeration lagoon system using the ordinary kriging (OK) interpolation method in ArcGIS10.1. In addition, based on Yellow Spring Instrument (YSI) continuous monitoring we characterized the diel $\mathrm{DO}, \mathrm{pH}$, turbidity, and conductivity dynamics of the system.

\section{Material and Methods}

\subsection{Study Area and Data Collection}

Cha-Am is a popular destination for local Thai and foreign day visitors due to its long strip of beach and relatively inexpensive seafood. There also is a growing long term stay population, shown by the construction of new condos, townhomes, and housing enclaves. Cha-Am is in the southern part of Phetchaburi Province, central Thailand (Figure 2).

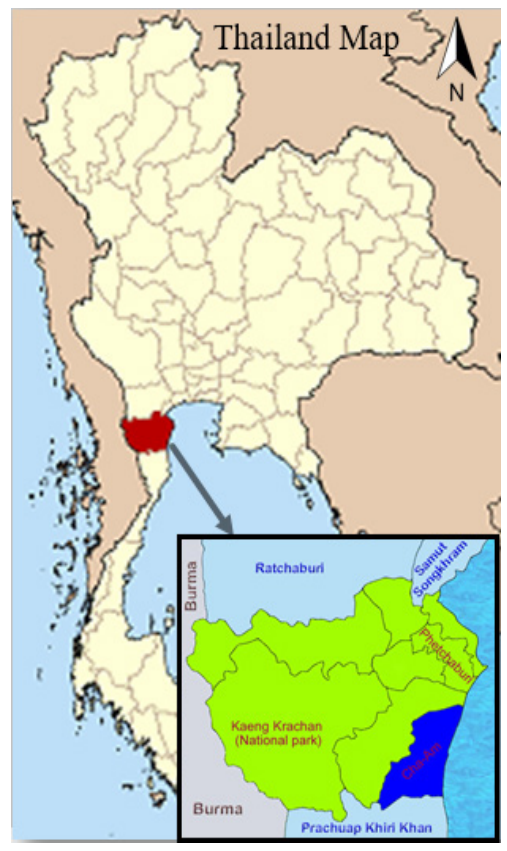

Figure 2 Thailand map and Cha-Am location.

As a result of the increase in population, there also is an increased water and wastewater treatment demand. Constructed in 2001, the Cha-Am municipality treatment ponds receive the wastewater discharges from the residential and commercial zones of the town. Wastewater is collected by a combined sewer system and pumped to the aerated lagoon centralized wastewater treatment system. The main components of the wastewater treatment system include: an aeration pond (AP); a sedimentation pond (SP); and an extended aeration pond (EAP). There is an additional natural treatment wetland, an evaporation pond, also known as the 
Tung Ta Kard Ple wetland, that receives the effluent from the EAP (Figure 3). Most of the treated wastewater evaporates, although a proportion $\left(\sim 5.83 \times 10^{-4} \mathrm{~m}^{3} / \mathrm{s}\right.$, during dry weather) discharges to the ocean via a small stream. The AP was constructed with eight mechanical aerators to help enhance oxygen levels (Figures 4 and $5)$.

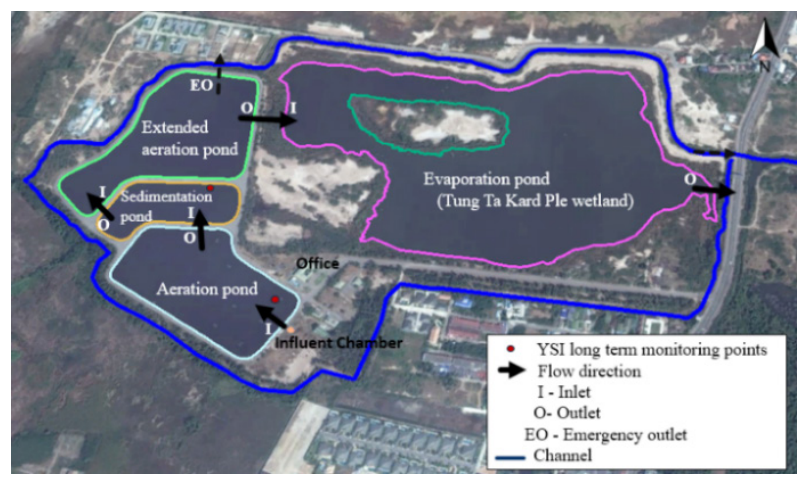

Figure 3 Cha-Am wastewater treatment ponds, flow direction and YSI datasonde long term monitoring point.

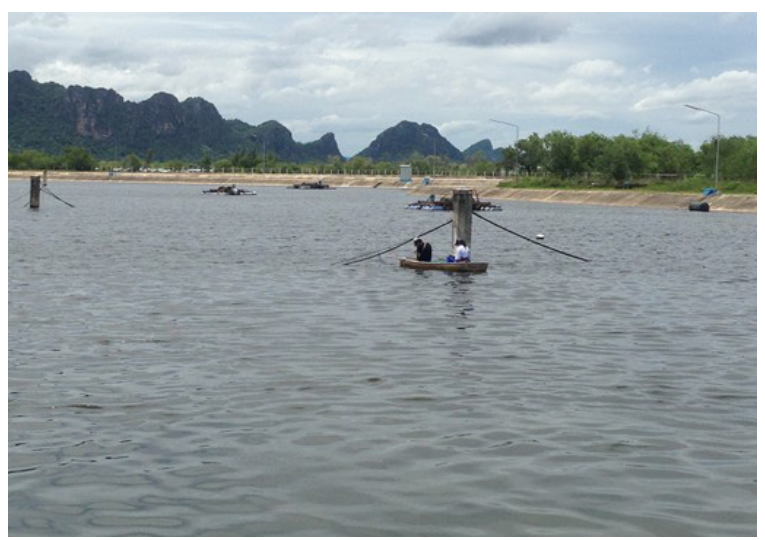

Figure 4 Aeration pond with aerators and researchers conducting YSI datasonde profiling.

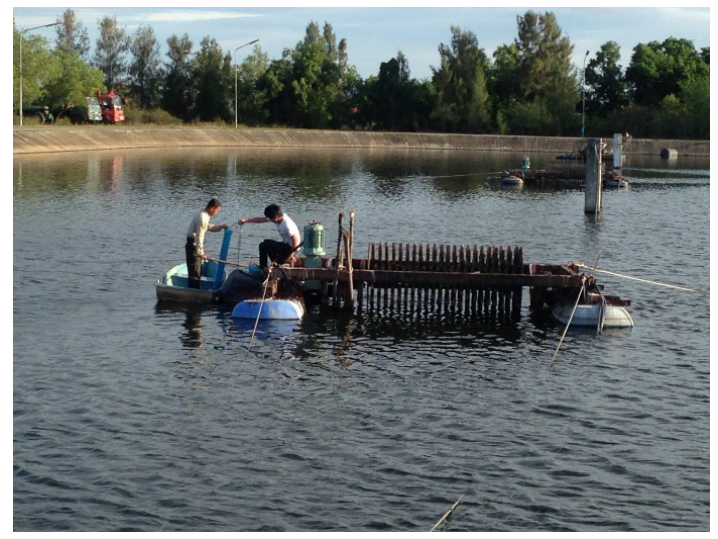

Figure 5 Installation of YSI datasonde near the aeration pond inlet, on the side of a mechanical aerator.
One YSI 6920 datasonde was deployed near the inlet of AP and a second at the opposite side of the SP inlet (Figure 3) to continuously record dissolved oxygen (DO), $\mathrm{pH}$, conductivity, temperature, and turbidity at $30 \mathrm{~min}$ time intervals. The YSIs were deployed from 2015-06-19-2015-09-12 19, and collected data at a depth of between $0.5 \mathrm{~m}$ to $1.0 \mathrm{~m}$, depending on the surface level fluctuations of the ponds (Figure 5). On the routine monitoring days (bi-weekly interval), the datasondes were cleaned and calibrated and all data downloaded. The DO sensors were calibrated using the $100 \%$ air saturation method, according to standard past practice (Irvine et al. 2005; Irvine and Murphy 2009; Irvine et al. 2011) and pH was calibrated with $\mathrm{pH} 4$ and $\mathrm{pH} 7$ buffer solutions. The YSI parameters in this study are commonly used to determine water quality (Irvine et al. 2005; Visoth et al. 2010; Irvine et al. 2011; Price et al. 2012). The YSIs also were used to profile water quality in all ponds at 3 different depths in $\geq 10$ sample locations for each pond (Figure 4). GIS ordinary kriging (OK) interpolation was used for these three profile depths, representing the upper layer $(0.5 \mathrm{~m}-1.0 \mathrm{~m})$, the middle layer $(1.0 \mathrm{~m}-1.5 \mathrm{~m})$ and the bottom layer of each pond. According to the YSI depth sensor, the depths of the bottom layers of AP, SP, EAP and EP were 2.9 $\mathrm{m}, \sim 2.29 \mathrm{~m}, \sim 1.69 \mathrm{~m}$ and $\sim 2 \mathrm{~m}$, respectively. Global positioning system (GPS) coordinates determined from an iPhone6 were used for georeferencing purposes. In total, profiling was done on 7 dates for AP and two dates for each ok SP, EAP and EP through the study period.

\subsection{GIS Ordinary Kriging Interpolation}

The geographic coordinates for each profile location were converted to a shapefile using ArcView3.3. ArcGIS10.1 Geostatistical Analyst tool (kriging interpolation) was then used to spatially interpolate DO surfaces based on the sample points. There are many different methods that can be used to investigate the spatial distribution of water quality (Murphy et al. 2010; Chen et al. 2012a), but OK has been widely used (Murphy et al. 2010 ; Lui et al. 2011; Chen et al. 2012a). OK provides a model of the unsampled value as a linear combination of neighboring observations. The general equation for estimating a value at a point $z$ (Chang 2012) is:

$$
z_{0}=\sum_{i=1}^{s} z_{x} W_{x}
$$

where:

$z_{0}=$ estimated value,

$z_{x}=$ known value at point $x$,

$W_{x}=$ weight associated with point $x$, and

$s=$ number of sample points used in estimation.

The weights can be derived by solving a set of simultaneous equations (Equations 3, 4 and 5). For example, the following equations are needed for a point ( 0 ) to be estimated from three known points (1, 2 and 3$)$ :

$$
\begin{aligned}
& W_{1} \cdot \gamma\left(h_{11}\right)+W_{2} \cdot \gamma\left(h_{12}\right)+W_{3} \cdot \gamma\left(h_{13}\right)+\lambda=\gamma\left(h_{10}\right) \\
& W_{1} \cdot \gamma\left(h_{21}\right)+W_{2} \cdot \gamma\left(h_{22}\right)+W_{3} \cdot \gamma\left(h_{23}\right)+\lambda=\gamma\left(h_{20}\right)
\end{aligned}
$$




$$
W_{1} \cdot \gamma\left(h_{31}\right)+W_{2} \cdot \gamma\left(h_{32}\right)+W_{3} \cdot \gamma\left(h_{33}\right)+\lambda=\gamma\left(h_{30}\right)
$$

and

$$
W_{1}+W_{2}+W_{3}=1.0
$$

where:

$$
\begin{aligned}
\gamma\left(h_{i j}\right)= & \text { semivariance between two known points ( } i \text { and } \\
& j \text { ), and } \\
\lambda= & \text { Lagrange multiplier or the weighting factor } \\
& \text { (which is added to ensure the minimum possible } \\
& \text { estimation error). }
\end{aligned}
$$

After deriving the weights, Equation 2 can be used to estimate $z_{0}$ :

$$
z_{0}=z_{1} W_{1}+z_{2} W_{2}+z_{3} W_{3}
$$

\section{Results and Discussions}

\subsection{GIS Ordinary Kriging Interpolation}

This study focused on the spatial distribution of DO in the Cha-Am wastewater treatment pond system. Selected representative kriging results, based on the YSI datasonde spot measurements, are presented in Figures 6 and 7 and in Figures 10 through 12 . The measured and kriging results show the highest DO concentrations to be near the surface $(0.5 \mathrm{~m}$ to $1.0 \mathrm{~m})$ of the ponds, and lower concentrations of DO (sometimes $<2 \mathrm{mg} / \mathrm{L}$ ) at approximately $0.5 \mathrm{~m}, 0.3 \mathrm{~m}, 0.3 \mathrm{~m}$ and $0.9 \mathrm{~m}$ above the bottom in AP, SP, EAP and EP respectively. The highest $D O$ concentrations were observed during the afternoon near the surface $(0.5 \mathrm{~m}$ to 1.0 $\mathrm{m}$ ), averaging $18.09 \mathrm{mg} / \mathrm{L}, 20.84 \mathrm{mg} / \mathrm{L}, 17.22 \mathrm{mg} / \mathrm{L}$ and $9.31 \mathrm{mg} / \mathrm{L}$ in AP, SP, EAP and EP respectively. The average minimum values were $2.3 \mathrm{mg} / \mathrm{L}, 2.91 \mathrm{mg} / \mathrm{L}, 2.23 \mathrm{mg} / \mathrm{L}$ and $1.5 \mathrm{mg} / \mathrm{L}$ in the bottom layer of AP, SP, EAP and EP respectively. Oxygen production occurs at the top of the pond, where photosynthesis and atmospheric mixing take place. Oxygen consumption is greatest near the bottom of the pond, where the organic matter accumulates and decomposes, sediment oxygen demand would have the greatest impact, and water light is attenuated sufficiently to reduce photo-synthetic activity. Our results are consistent with those reported by Murphy et al. 2010 and Chen et al. 2012a.

The mean DO value concentrations and standard deviation in the upper layers $(0.5 \mathrm{~m}$ to $1.0 \mathrm{~m})$, middle layers $(1.0 \mathrm{~m}$ to 1.5 $\mathrm{m}$ ) and the bottom layers of all ponds are shown in Table 2. In AP, the DO levels were normally lower at the inlet and higher at the outlet (4 dates out of 7 dates, Figure 6), but on 3 dates, the reverse spatial trend occurred due to a shift in the wind direction and velocity (Figure 7). The aeration pond of the Cha-Am wastewater treatment pond system was designed to maintain a consistent DO level. It has eight aerators to maintain DO levels for wastewa-ter management. The other treatment ponds also have a suitable DO for fish (Figure 8).
Table 2 Mean value concentrations and standard deviation of dissolved oxygen in all ponds $(\mathrm{mg} / \mathrm{L})$.

\begin{tabular}{ccccccc}
\hline & \multicolumn{2}{c}{ Upper Layer } & \multicolumn{2}{c}{ Middle Layer } & \multicolumn{2}{c}{ Bottom Layer } \\
& Mean & St Dev & Mean & St Dev & Mean & St Dev \\
\hline AP & & & & & & \\
$2015-06-19$ & 11.98 & 5.14 & 8.14 & 4.20 & 5.18 & 2.51 \\
$2015-07-04$ & 10.96 & 1.99 & 7.70 & 1.79 & 3.18 & 0.00 \\
$2015-08-05$ & 8.93 & 2.72 & 5.86 & 1.52 & 2.89 & 0.70 \\
$2015-08-22$ & 17.76 & 3.59 & 14.62 & 4.84 & 10.64 & 4.75 \\
$2015-08-29$ & 11.24 & 2.55 & 8.56 & 3.15 & 3.92 & 0.65 \\
$2015-09-05$ & 10.88 & 4.62 & 7.96 & 4.11 & 3.23 & 1.12 \\
$2015-09-12$ & 11.18 & 2.37 & 6.42 & 2.84 & 3.47 & 1.00 \\
\hline SP & & & & & & \\
$2015-07-27$ & 10.07 & 2.96 & 7.43 & 3.16 & 5.12 & 0.53 \\
$2015-08-05$ & 11.60 & 4.72 & 9.98 & 5.14 & 4.74 & 2.99 \\
$2015-09-12$ & 18.20 & 1.84 & 13.33 & 0.58 & 5.47 & 0.24 \\
\hline EAP & & & & & & \\
$2015-07-04$ & 5.65 & 2.74 & 5.17 & 2.57 & 2.81 & 1.82 \\
$2015-07-27$ & 15.27 & 1.62 & 10.83 & 3.53 & 10.99 & 3.53 \\
$2015-09-12$ & 14.66 & 3.37 & 11.56 & 2.92 & 6.55 & 1.29 \\
\hline EP & & & & & & \\
$2015-07-19$ & 4.66 & 1.38 & 3.63 & 1.64 & 2.63 & 1.74 \\
$2015-08-15$ & 7.40 & 1.91 & 6.15 & 1.78 & 4.66 & 1.29 \\
\hline
\end{tabular}

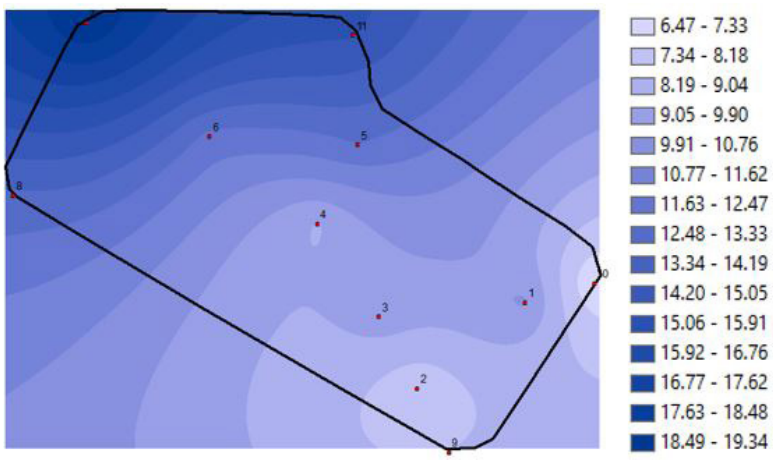

Figure 6a DO variation in upper layer of the aeration pond, AP, mg/L; 2015-08-29.

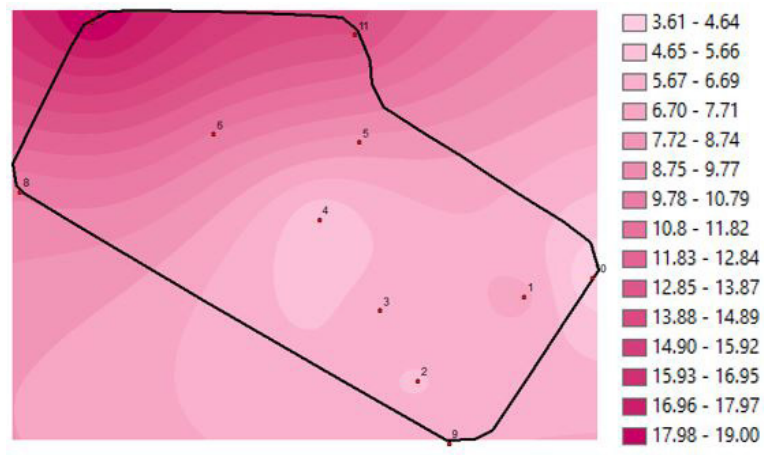

Figure $6 \mathrm{~b}$ DO variation in middle layer of the aeration pond, AP, mg/L; 2015-08-29. 


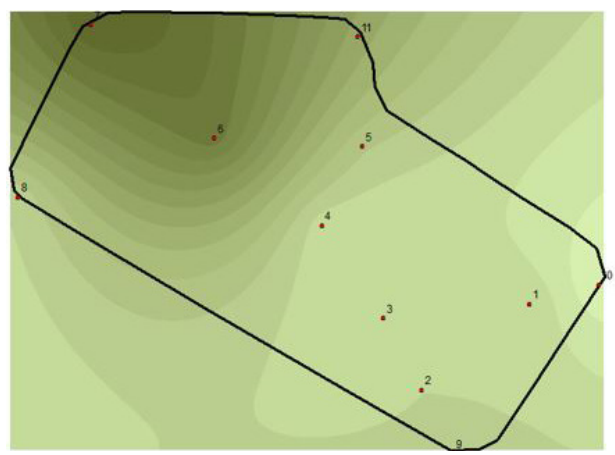

$\square 3.00-3.19$ $\square 3.20-3.38$ $\square 3.39-3.56$ $\square 3.57-3.75$ $\square 3.76-3.94$ $\square 3.95-4.12$ $4.13-4.31$ $\square 4.32-4.50$ $\square .51-4.68$ $\square 4.69-4.87$ $\square .88-5.05$ $5.06-5.24$ $5.25-5.43$ $5.44-5.61$ $5.62-5.80$

Figure 6c DO variation in bottom layer of the aeration pond, AP, mg/L; 2015-08-29.

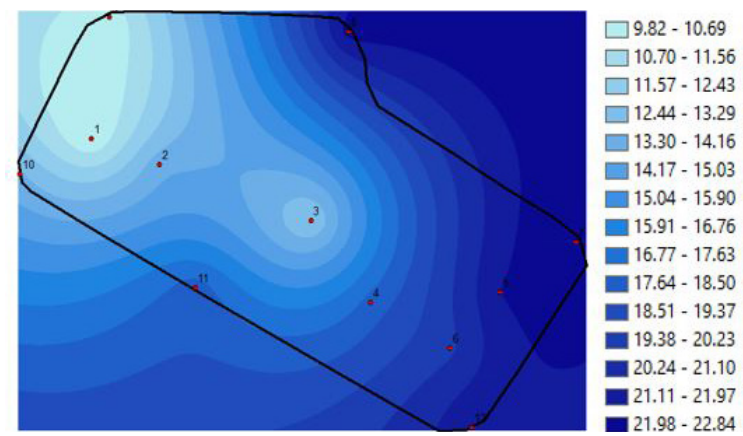

Figure 7a DO variation in upper layers of the aeration pond, $\mathrm{AP}, \mathrm{mg} / \mathrm{L} ; 2015-08-22$ in windy conditions.

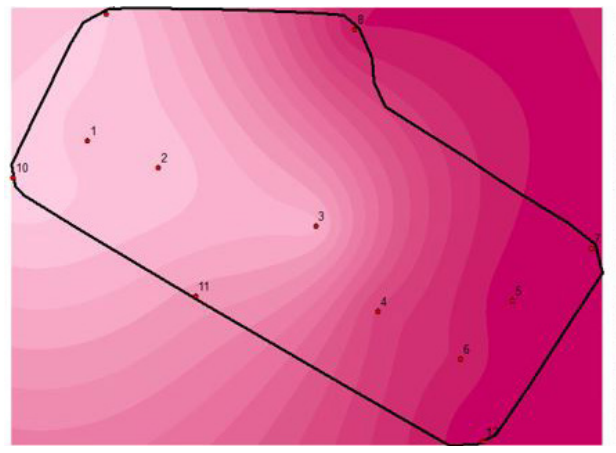

$\square 6.73-7.70$ $\square 7.71-8.68$ $\square 8.69-9.65$ $\square 9.66-10.63$ $\square 10.64-11.60$ $\square 11.61-12.58$ $\square 12.59-13.55$ $\square 13.56-14.53$ $14.54-15.50$ $\square 15.51-16.48$ $16.49-17.45$ $17.46-18.43$ $18.44-19.40$ $19.41-20.38$

Figure $7 \mathrm{~b}$ DO variation in middle layer of the aeration pond, AP, mg/L; 2015-08-22 in windy conditions.

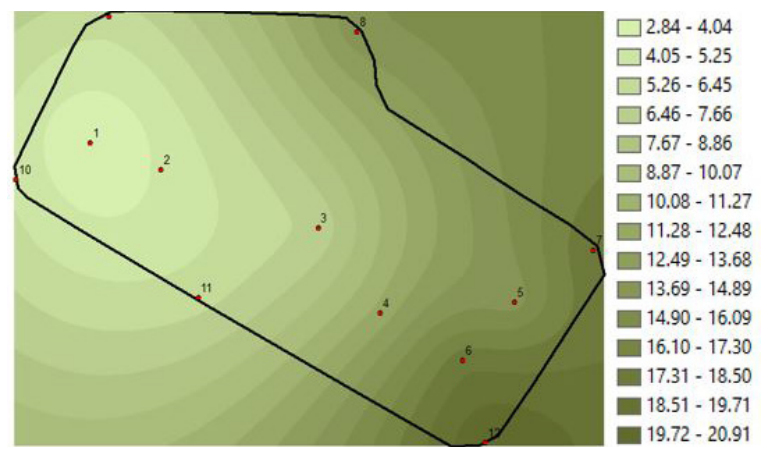

Figure 7c DO variation in bottom layer of the aeration pond, $\mathrm{AP}, \mathrm{mg} / \mathrm{L} ; 2015-08-22$ in windy conditions.

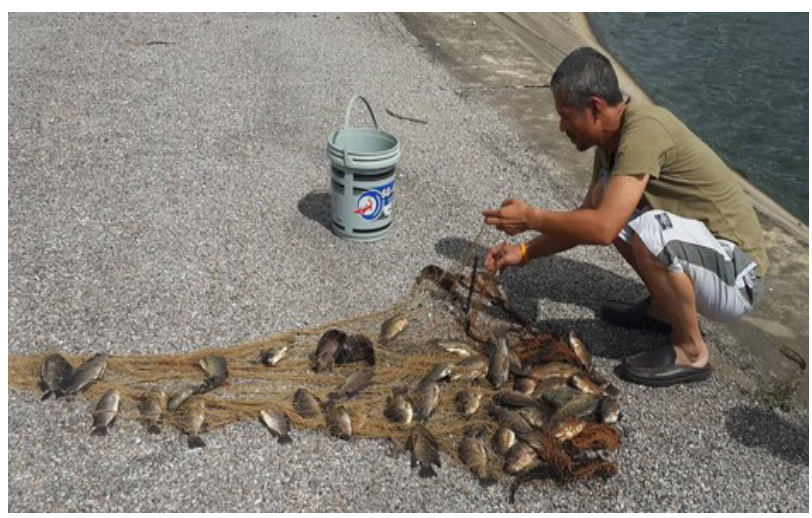

Figure 8 Local person fishing in extended aeration pond.

The aerators in AP were generally operated for two hours ( 06:00 $\mathrm{h}$ to 08:00 h) every weekday and for more than two hours on the weekend. Tilapia are an active fish species in the Cha-Am wastewater treatment ponds. Tilapia tolerate lower DO levels but the levels still should be greater than $1 \mathrm{mg} / \mathrm{L}$ (Boyd 2010). Due to low DO overnight DO levels (see the next section on continuous monitoring) fish may die in the ponds and we observed fish gulping at the surface especially early in the morning (Figure 9).

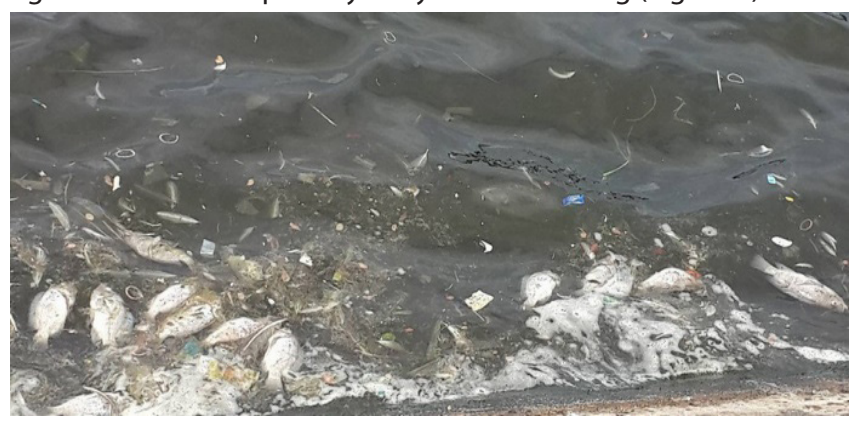

Figure 9 Frequent fish deaths in sedimentation pond.

The DO concentration in the bottom layer was quite low, even during the day, being $<2 \mathrm{mg} / \mathrm{L}$ in some areas of each pond. The lowest values of DO were $1.4 \mathrm{mg} / \mathrm{L}, 1.05 \mathrm{mg} / \mathrm{L}, 0.76 \mathrm{mg} / \mathrm{L}$ and $0.4 \mathrm{mg} / \mathrm{L}$ in AP, SP, EAP and EP respectively. Figure 10 shows DO interpolation for the SP. The DO level for all layers of SP was sometimes higher and sometimes lower at the outlet of the pond. However, we consistently observed a dead zone in the west corner of the pond due to poor hydraulic design.

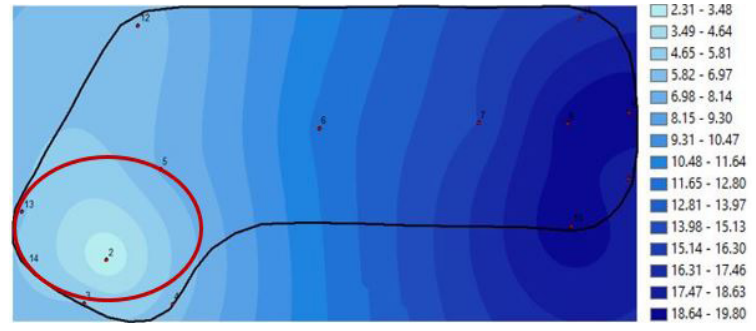

Figure 10a DO variation in upper layer of the sedimentation pond, SP, mg/L; 2015-08-05 (red ellipse shows the dead zone of DO). 

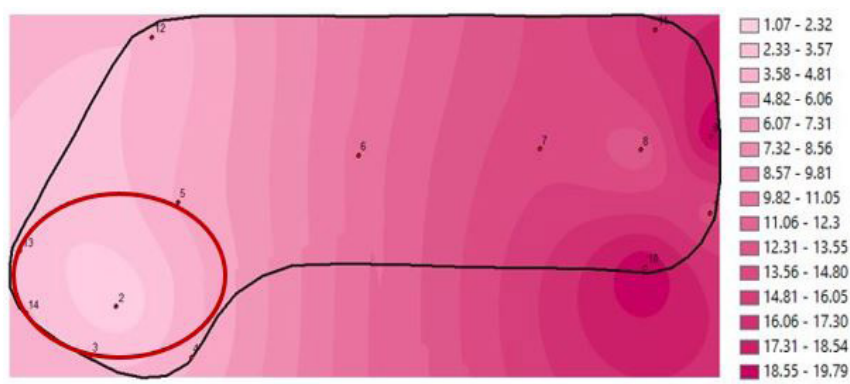

Figure 10b DO variation in middle layer of the sedimentation pond, SP, mg/L; 2015-08-05 (red ellipse shows the dead zone of DO).

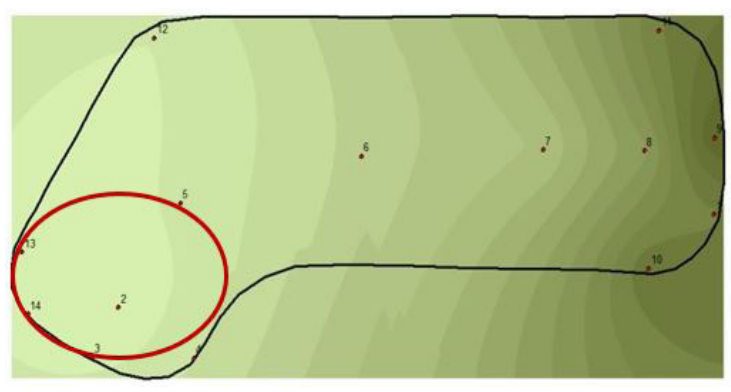

$\square 1.05-1.82$ $1.83 \cdot 2.60$ $\square 2.61 \cdot 3.37$ $3.38-4.15$ $\square 4.16-4.92$ $\square 4.93 \cdot 5.70$ $5.71 \cdot 6.47$ $\square .48-7.25$ $6.48-7.25$
$7.26-8.02$ $8.03-8.80$ $8.81-9.57$ 뭉.58- 10.35 $=10.36-11.12$ $11.13 \cdot 11.90$ $11.13 \cdot 11.90$
$11.91 \cdot 12.67$

Figure 10c DO variation in bottom layer of the sedimentation pond, SP, mg/L; 2015-08-05 (red ellipse shows the dead zone of DO).

The DO at the outlet of the EAP was normally higher than it was at the inlet (Figure 11). As noted above (see Figure 1 and Equation 1), DO can be generated by algae, plants and bacteria as a byproduct of photosynthesis and denitrification. In SP and $E P$, algae and other plants added oxygen to the water during the daytime hours, which is consistent with the findings of Visoth et al. (2010) for the natural wastewater treatment wetland in Phnom Penh.

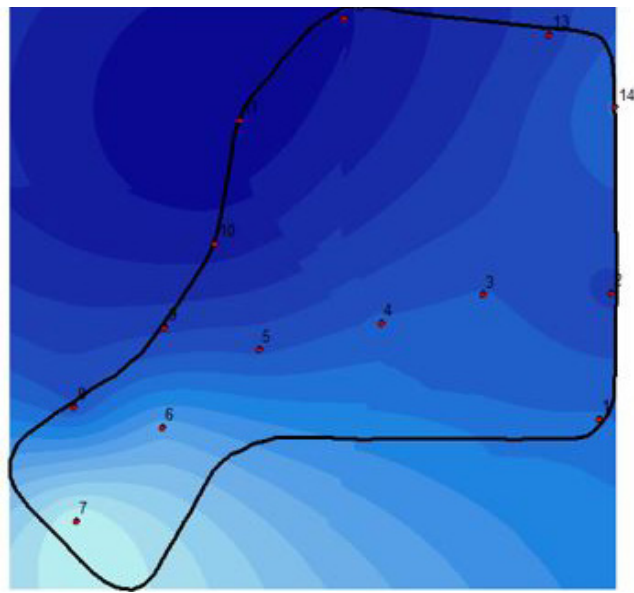

$\square 10.88-11.33$

$11.34-11.77$

$11.78-12.21$

$12.22-12.66$

$12.67-13.10$

$13.11-13.54$

$13.55-13.98$

$13.99-14.43$

$14.44-14.87$

$14.88-15.31$

$15.32-15.76$

$15.77-16.20$

$16.21-16.64$

$16.65-17.08$

$17.09-17.53$

Figure 11a DO variation in upper layer of the extended aeration pond, EAP, mg/L); 2015-07-27.
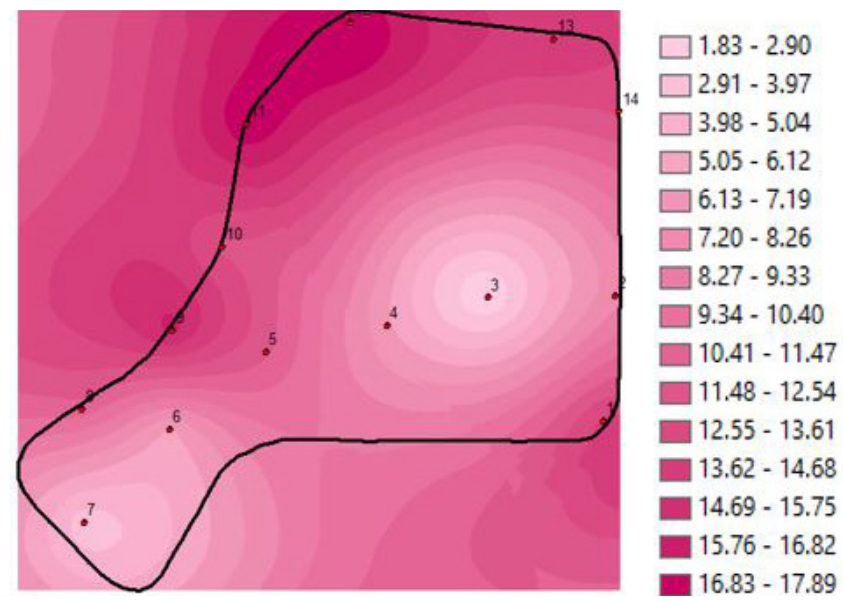

Figure 11b DO variation in middle layer of the extended aeration pond, EAP, mg/L; 2015-07-27.
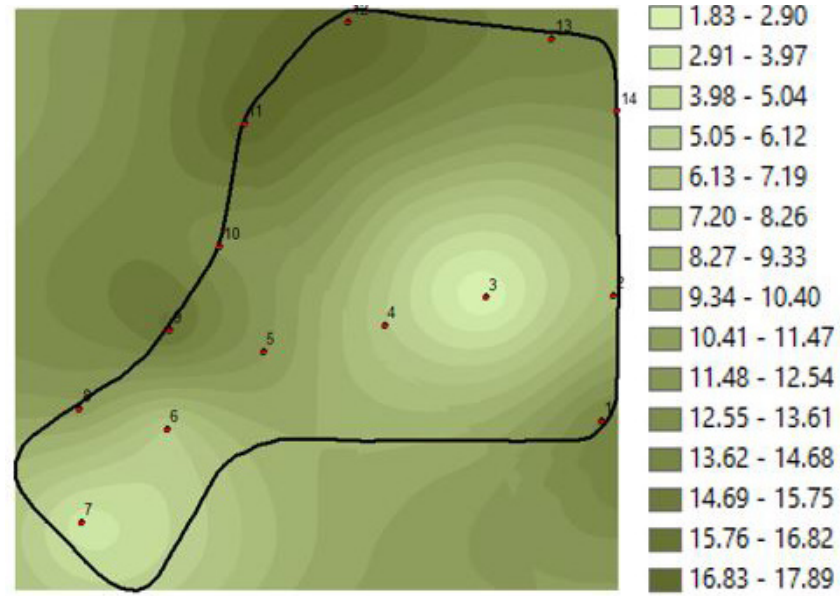

Figure 11c DO variation in bottom layer of the extended aeration pond, EAP, mg/L); 2015-07-27.

In EP the DO level was consistently higher at the inlet than at the outlet (Figure 12). This is a concern since the water leaving EP flows down a small receiving stream into the ocean and there is thus potential for negative impact on the small stream. Generally, however, DO levels from the EP discharge are quite high, despite the reduction in levels from pond inlet to outlet.
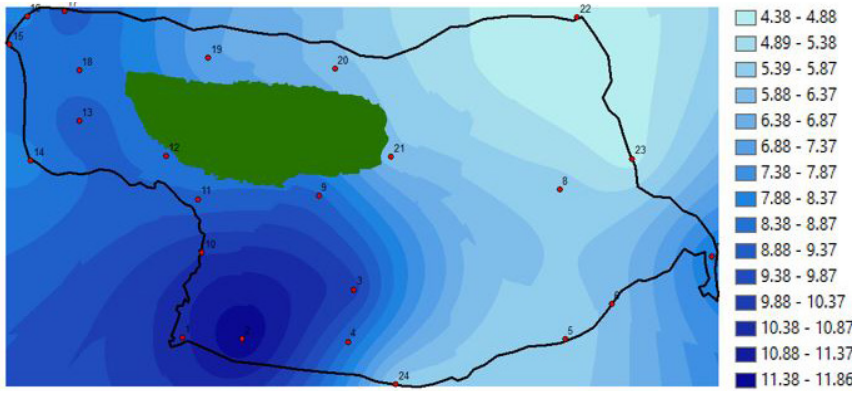

Figure 12a DO variation in upper layer of the evaporation pond, $\mathrm{EP}, \mathrm{mg} / \mathrm{L}$; 2015-08-15 (the green shaded area is an island with natural plants). 


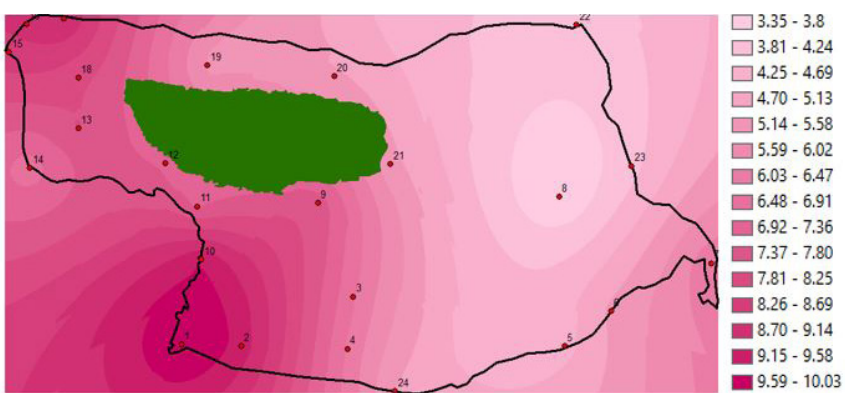

Figure 12b DO variation in middle layer of the evaporation pond, $\mathrm{EP}, \mathrm{mg} / \mathrm{L}$; 2015-08-15 (the green shaded area is an island with natural plants).

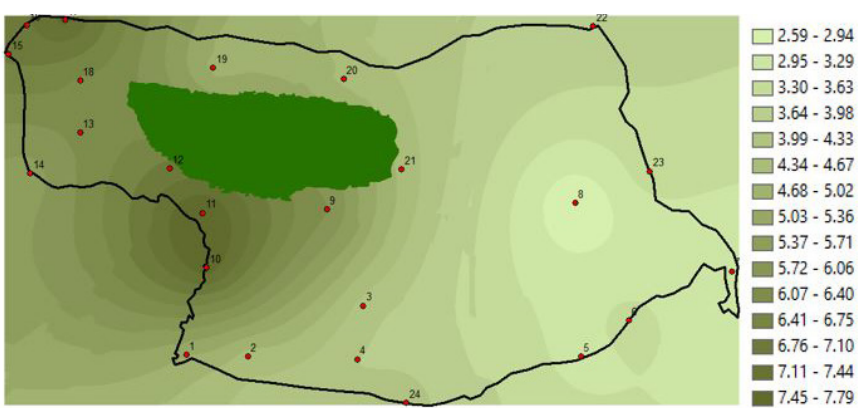

Figure 12c DO variation in bottom layer of the evaporation pond, EP, mg/L; 2015-08-15 (the green shaded area is an island with natural plants).

\subsection{YSI Continuous Monitoring Results}

The DO levels often displayed considerable variation over a diel cycle, with the higher values (supersaturated) appearing in midafternoon and low values occurring after midnight in typical sampling days (Figure 13). Similar results have been reported for natural treatment wetlands, canals and lakes in Southeast Asia (Visoth et al. 2010; Irvine et al. 2011; Price et al. 2012). In AP the DO level was noticeably influenced by aerator operation which generally occurred between 06:00 $\mathrm{h}$ and 08:00 h (Figure 13).

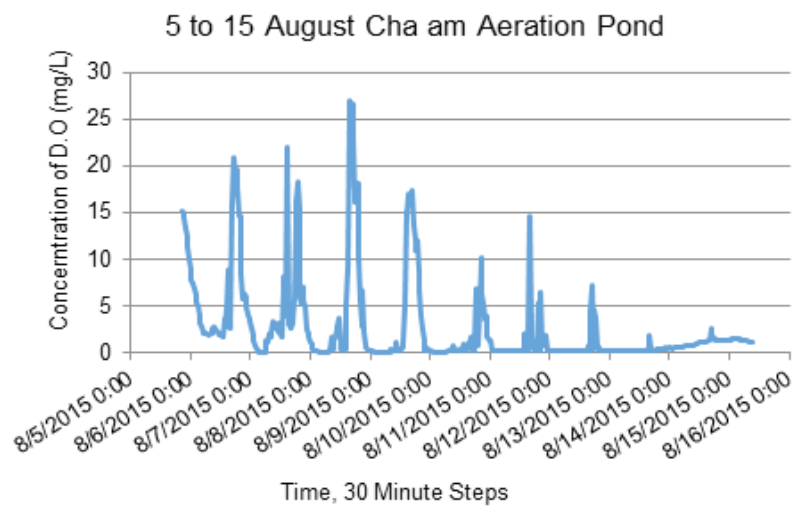

Figure 13a DO fluctuation in the aeration pond, AP, for the period 2015-08-05-2015-08-15.

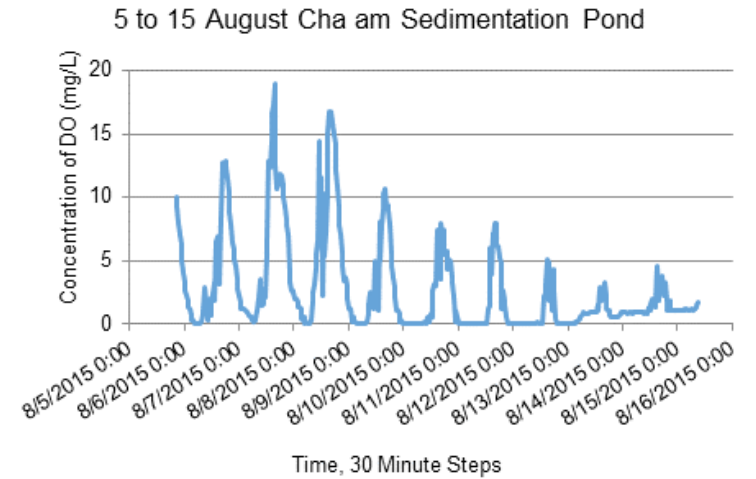

Figure 13b DO fluctuation in the sedimentation pond, SP, for the period 2015-08-05-2015-08-15.

Table 3 summarizes the mean and standard deviation of $\mathrm{DO}, \mathrm{pH}$, conductivity, temperature and turbidity for the AP and SP sites as well as the rainfall amount for each period.

Table 3 Mean values of long term monitoring $\mathrm{DO}, \mathrm{pH}$, temperature, conductivity and turbidity in the aeration pond and the sedimentation pond, together with rainfall data (2015-06-19-2015-09-15).

\begin{tabular}{|c|c|c|c|c|c|c|c|c|c|c|c|}
\hline & \multicolumn{2}{|c|}{ DO (mg/L) } & \multicolumn{2}{|c|}{$\mathrm{pH}$} & \multicolumn{2}{|c|}{$\operatorname{Temp}\left({ }^{\circ} \mathrm{C}\right)$} & \multicolumn{2}{|c|}{$\begin{array}{c}\text { Conductivity } \\
(\mathrm{mS} / \mathrm{cm})\end{array}$} & \multicolumn{2}{|c|}{$\begin{array}{l}\text { Turbidity } \\
\text { (NTU) }\end{array}$} & \multirow[t]{2}{*}{$\begin{array}{l}\text { Rain- } \\
\text { fall } \\
(\mathrm{mm})\end{array}$} \\
\hline & AP & $S P$ & AP & $S P$ & AP & SP & AP & SP & AP & SP & \\
\hline $\begin{array}{l}2015-06-19 \\
-2015-07-04\end{array}$ & 3.91 & 4.32 & 7.61 & 8.88 & 31.03 & 30.67 & 6.49 & 7.05 & 10.13 & 18.83 & 1.56 \\
\hline $\begin{array}{l}2015-07-04 \\
-2015-07-15 \\
2015-07-15\end{array}$ & 1.38 & 2.18 & 8.40 & - & 31.01 & 30.71 & 5.37 & 5.64 & 198.56 & 170.1 & 0.53 \\
\hline $\begin{array}{l}-2015-07-27 \\
2015-07-27\end{array}$ & 3.21 & 4.97 & 7.81 & 7.88 & 30.85 & 30.47 & 5.59 & 5.41 & 36.57 & 26.48 & 0.44 \\
\hline $\begin{array}{l}-2015-08-05 \\
2015-08-05\end{array}$ & 2.74 & 4.78 & 7.31 & 7.69 & 30.79 & 30.37 & 4.65 & 5.09 & 15.12 & 13.39 & 16.67 \\
\hline $\begin{array}{l}-2015-08-15 \\
2015-08-15\end{array}$ & 2.84 & 2.80 & 7.46 & 7.50 & 31.02 & 31.00 & 4.16 & 4.69 & 254.87 & 16.04 & 0.09 \\
\hline $\begin{array}{l}-2015-08-22 \\
2015-08-22\end{array}$ & 2.87 & 4.34 & 7.12 & 7.61 & 31.77 & 31.56 & 3.96 & 4.25 & 30.34 & 15.13 & 0.25 \\
\hline $\begin{array}{l}-2015-08-29 \\
2015-08-29\end{array}$ & 4.72 & 2.43 & 7.16 & 7.47 & 30.77 & 30.34 & 3.45 & 3.87 & 11.99 & 19.96 & 2.50 \\
\hline $\begin{array}{l}-2015-09-05 \\
2015-09-05\end{array}$ & 4.33 & 1.86 & 7.14 & 7.42 & 31.15 & 30.99 & 3.94 & 3.82 & 8.19 & 26.64 & 5.13 \\
\hline$-2015-09-12$ & 2.67 & 2.91 & 7.04 & 7.67 & 31.44 & 31.28 & 3.54 & 3.72 & 10.29 & 291.37 & 9.28 \\
\hline
\end{tabular}

The overall average of DO in both of the ponds was slightly $>3 \mathrm{mg} / \mathrm{L}$ during the entire monitoring period, and $3.09 \mathrm{mg} / \mathrm{L}$ and $3.33 \mathrm{mg} / \mathrm{L}$ for AP and SP respectively. These values fall into Thailand's class 4, within the sampling period (Simachaya, 2002). DO in AP may be slightly lower than DO in SP because of the different depth of monitoring (AP: $0.9 \mathrm{~m}$ depth; and SP: $0.5 \mathrm{~m}$ depth) and the impact of inflowing raw wastewater. The $t$-test (two-sample assuming equal variances) was also used to assess whether the differences in the means ( $3.09 \mathrm{mg} / \mathrm{L}$ for $\mathrm{AP}$ and $3.33 \mathrm{mg} / \mathrm{L}$ for SP) were significant. The $p$-value was $>0.05$, and therefore the difference in means between AP and SP was not significant.The mean $\mathrm{pH}$ values were in the range $\mathrm{pH} 7$ to $\mathrm{pH} 9$ at both ponds and the 
values were quite constant during the entire monitoring period, except in the period 2015-07-04-2015-07-15 (Table 3). In this period the $\mathrm{pH}$ sensor malfunctioned.

Generally, the conductivity at the two sites was high and likely reflects known seawater seepage into the collection system and ponds (Anant Bootengchan, treatment pond operator, pers. comm.). Conductivity continuously declined during the last three sample periods (August and September) probably due to dilution effects associated with the onset of the rainy season (see the rainfall in Table 3). A high conductivity also can negatively impact growth of Tilapia (Iqbal et al. 2012).

The mean values of temperature at the two sites shows a similar fluctuation, in which the peak temperature occurred during the period 2015-08-15-2015-08-22 and the lowest temperature occurred during the period 2015-08-22-2015-08-29 (Table 3). The highest turbidity in AP occurred because of the heavy rainfall during June and August (although a lag seems to occur) and the highest turbidity in SP in September was due to the continuous rainfall (Table 3 ). The mean value of turbidity in AP was higher than it was in SP over the sampling period.

\section{Conclusions}

Spatial trends of DO at different depths in Cha-Am wastewater treatment ponds were examined using ordinary kriging in ArcGIS10.1. The DO concentration at the bottom layer was quite low even during the daylight hours. In some areas of the bottom layer, DO was $<2 \mathrm{mg} / \mathrm{L}$. The spatial trend of DO in AP and EAP was normally such that the values at the inlet values were lower than the values at the outlet (although this trend could reverse under certain changes in wind speed and wind direction for AP). In SP the spatial variation of DO was not consistent. Sometimes the inlet DO was lower and sometimes it was higher than the outlet DO. A DO dead zone was clearly visible in the kriging results and seems to be related to the hydraulics of the pond system. The DO in the evaporation pond was consistently higher at the inlet and lower at the outlet. Based on the GIS spatial trend and long term datasonde monitoring, DO concentrations were compared with Thailand's surface water quality standards, which are regulated by the Pollution Control Department. The original design of the Cha-Am wastewater treatment system is between $2 \mathrm{mg} / \mathrm{L}$ and $4 \mathrm{mg} / \mathrm{L}$ (the same as class 4 ). The dissolved oxygen concentrations met Thailand's water quality standard for class 4 . In order to meet the class 3 standard the wastewater treatment system operation must be modified. In the Cha-Am wastewater treatment pond system, DO concentration can be affected by a number of factors such as aeration, seawater movement, rainfall, algae growth and consumption by other aquatic living organisms, and oxygen production and use by aquatic plants in the ponds. Based on the DO diel trends and the GIS kriging interpolation results, aerators should be operated $>2 \mathrm{~h} / \mathrm{d}$ to supply sufficient oxygen in the AP. In addition, aerators should operate during the night time when DO is low. A future study to investigate whether the aerators are optimally positioned to enhance DO levels is needed. The
DO concentration should be sufficient to provide the optimal conditions for the growth of aquatic organisms in the wastewater treatment pond. The hydraulic retention time of the ponds might be increased to settle particles and allow greater sunlight penetration. Continuous long term monitoring of water quality parameters is a useful tool to identify the efficiency of wastewater treatment.

\section{Acknowledgment}

Funding for this research was provided by a scholarship from the Government of Norway's Capacity Building for Institutions in Myanmar project. Furthermore, thanks to Mr. Anant Bootengchan for his kind support throughout this research work at the Cha-Am Municipality Wastewater Treatment Plant.

\section{References}

Andrews, W. A. and S. J. McEwan. 1987. Investigating Aquatic Ecosystems. Scarborough, Ontario: Prentice-Hall Canada.

Bartsch, E. H. and C. W. Randall. 1971. “Aerated Lagoons: A Report on the State of the Art." Journal (Water Pollution Control Federation) 43 (4): 699-708.

Boyd, C. E. 2010 “Dissolved Oxygen Concentrations in Pond Aquaculture." Global Aquaculture Advocate 2010 (January/February): 40-1.

Chang, K. 2012. Introduction to Geographic Information Systems, 6th ed. Upper Saddle River, NJ: McGraw-Hill.

Chen, W. B., W. C. Liu and L. T. Huang. 2012a, "Measurement of Sediment Oxygen Demand for Modeling the Dissolved Oxygen Distribution in a Subalpine Lake." International Journal of Physical Sciences 7 (27): 5036-48.

Chen, Y. C., H. C. Yeh and C. Wei. 2012b. “Estimation of River Pollution Index in a Tidal Stream Using Kriging Analysis." International Journal of Environmental Research and Public Health 9:3085-100. https://doi.org/10.3390/ijerph9093085

Correa-Gonzalez, J. C., M. C. Chavez-Parga, J. A. Cortes and P. M. Perez-Munguia. 2014. "Photosynthesis, Respiration and Reaeration in a Stream with Complex Dissolved Oxygen Pattern and Temperature Dependence." Ecological Modelling 273:220-7. https://doi.org/10.1016/j.ecolmodel.2013.11.018

Forsythe, K. W., A. Gawedzki, P. Rodriguez, K. N. Irvine and M. Perrelli. 2013. "Geospatial Estimation of Mercury Contamination in Buffalo River Sediments." Journal of Soil and Sediment Contamination 21:521-31.

Iqbal, K. J., N. A. Qureshi, M. Ashraf, M. H. U Rehman, N. Khan, A. Javid, F. Abbas, M. M. H. Mushtaq, F. Rasool and H. Majeed. 2012. "Effect of Different Salinity Levels on Growth and Survival of Nile Tilapia (Oreochromis Niloticus)." Journal of Animal and Plant Science 22 (4): 919-22. 
Irvine, K. N., J. E. Richey, G. W. Holtgrieve, J. Sarkkula and M. Sampson. 2011. "Spatial and Temporal Variability Of Turbidity, Dissolved Oxygen, Conductivity, Temperature, and Fluorescence in the Lower Mekong River-Tonle Sap System Identified Using Continuous Monitoring." International Journal of River Basin Management 9 (2): 151-68. https://doi.org/10.1080/15715124.2011.621430

Irvine, K. N. and T. P. Murphy. 2009. "Assessment of Eutrophication and Phytoplankton Community Impairment in the Buffalo River Area of Concern." Journal of Great Lakes Research 35:83-93.

Irvine, K. N., G. McCorkhill and J. Caruso. 2005. “Continuous Monitoring of Conventional Parameters to Assess Receiving Water Quality in Support of CSO Abatement Plans." Water Environment Research 77 (5): 543-52.

Irvine, K. N., M .F. Perrelli, R. Ngoen-Klan and I. G. Droppo. 2009. "Metal Levels in Street Sediment from an Industrial City: Spatial Trends, Chemical Fractionation, and Management Implications." Journal of Soils and Sediments 9:328-41.

Ling, L., Q. Chunli, Q. Peng, Y. Zhifeng and G. Qianhong. 2010. “Numerical Simulation of Dissolved Oxygen Supersaturation Flow over the Three Gorges Dam Spillway." Tsinghua Science and Technology 15:574-79.

Lui, W. C., H. L. Yu and C. E. Chung. 2011. "Assessment of Water Quality in a Subtropical Alpine Lake Using Multivariate Statistical Techniques and Geostatistical Mapping: A Case Study." International Journal of Environmental Research and Public Health 8:1126-40. https://doi.org/10.3390/ijerph8041126

McBride, G. B. and S. C. Chapra. 2005. "Rapid Calculation of Oxygen in Streams: Approximate Delta Method." Journal of Environmental Engineering 131:336-42.

Misra, A. K., P. Chandra and J. B. Shukla. 2006. "Mathematical Modeling and Analysis of the Depletion of Dissolved Oxygen in Water Bodies." Nonlinear Analysis: Real World Applications 7 (5): 980-96.

https://doi.org/10.1016/j.nonrwa.2005.09.002
Murphy, R. R., F. C. Curriero and W. P. Ball. 2010. “Comparison of Spatial Interpolation Methods for Water Quality Evaluation in the Chesapeake Bay." Journal of Environmental Engineering 136 (2): 160-71. https://doi.org/10.1061/_ASCE_EE.1943-7870.0000121

Odum, H. T. 1956. "Primary Production in Flow Waters." Limnology and Oceanography 1:102-17.

Price, J., T. Chaosakul, N. Surinkul, J. Bowles, S. Rattanakul et al. 2012. "Surface Water Quality and Risk Analysis in a Peri-Urban Area, Thailand." https://www.researchgate.net/profile/Nirakar_Pradhan/ publication/276204669_Surface_Water_Quality_and_ Risk_Analysis_in_a_Peri-urban_Area_Thailand/links/ 555221f008ae6fd2d81d4271.pdf?origin=publication_list

Radwan, M., P. Willems, A. El-Sadek and J. Berlamont. 2003. "Modeling of Dissolved Oxygen and Biochemical Oxygen Demand in River Water Using a Detailed and a Simplified Model." International Journal of River Basin Management 1 (2): 97-103.

Richard, M. (2003). Microbiological and Chemical Testing for Troubleshooting Lagoons. Augusta, ME: State of Maine Department of Environmental Protection. http://www.lagoonsonline.com/trouble-shooting-wastewater-lagoons.htm

Sakalauskiene, G. 2001. “Dissolved Oxygen Balance Model for Neris." Nonlinear Analysis: Modelling and Control 6 (1): 105-31.

Simachaya, W. 2002. “Water Quality Monitoring and Modeling Application in Thailand." http://www.wepa-db.net/pdf/0810forum/paper17.pdf

USEPA (U.S. Environmental Protection Agency). 2012. “Dissolved Oxygen and Biochemical Oxygen Demand."Washington, DC: United States Environmental Protection Agency. https://archive.epa.gov/water/archive/web/html/vms52. html

Visoth, T., M. Yim, S. Vathna, K. N. Irvine and T. Koottatep. 2010. "Efficiency of Phnom Penh's Natural Wetlands in Treating Wastewater Discharges." Asian Journal of Water, Environment and Pollution 7 (3): 39-48. 